\title{
Africanization and the Reform of International Investment Law
}

Olabisi D. Akinkugbe

Follow this and additional works at: https://scholarlycommons.law.case.edu/jil

Part of the International Law Commons

\section{Recommended Citation}

Olabisi D. Akinkugbe, Africanization and the Reform of International Investment Law, 53 Case W. Res. J. Int'I L. 7 (2021)

Available at: https://scholarlycommons.law.case.edu/jil/vol53/iss1/4

This Article is brought to you for free and open access by the Student Journals at Case Western Reserve University School of Law Scholarly Commons. It has been accepted for inclusion in Case Western Reserve Journal of International Law by an authorized administrator of Case Western Reserve University School of Law Scholarly Commons. 


\title{
AFRICANIZATION AND THE REFORM OF INTERNATIONAL INVESTMENT LAW
}

\author{
Olabisi D. Akinkugbe*
}

Abstract

Recent trends in reforms by African states in the field of International Investment Law ("IIL") have been dubbed as the Africanization of IIL. These important debates regarding reform of IIL in Africa foreground innovative aspects of International Investment Agreements ("IIA") in contrast to the traditional IIL regime. The debates also remind us of the relative lack of African voices in the global IIL reform agenda. There is, however, little research that critically analyzes the Africanization of IIL thesis. This article undertakes this analysis. Drawing on TWAIL, this article characterizes Africanization of IIL into "moderate" and "radical" reforms. The article analyzes the normative features of Africanization of IIL. In this regard, it enriches existing substantive analysis, and advances the debates by interrogating the contours and blind spots of Africanization in IIL. It argues that the Africanization thesis, being so far limited to the IIAs between African states, is a "moderate" response from below to the systemic inequities of the IIL regime. Moderate Africanization of IIL a modest and incremental approach to the reform of IIL - engenders challenges for African states as they remain nestled in the neoliberal paradigm. To address this deficit and expand the geographies of African centered IIAs to reform and remake IIL, this article makes the case for a cascading of the Africanization thesis in more radical normative form based on a constellation of strategic moderate changes.

\section{TABle of Contents}

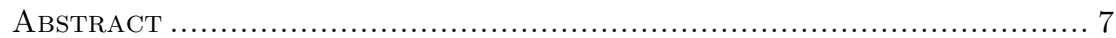

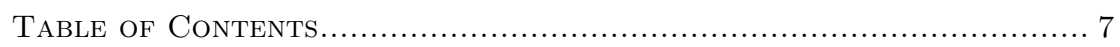

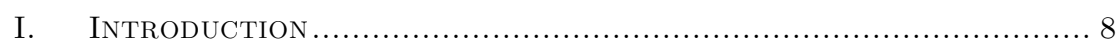

II. Moderate vs Radical Africanization of IIL .......................... 12

* Olabisi D. Akinkugbe is an Assistant Professor at the Schulich School of Law, Dalhousie University, Canada, and an Adjunct Visiting Assistant Professor, at the Fletcher School of Law and Diplomacy, Tufts University, U.S.A. He is also a co-founding editor of Afronomicslaw.org blog which focuses on all aspects of international economic law as they relate to Africa and the Global South, and the African Journal of International Economic Law (AfJIEL). 
III. Africanization of International Investment LaW ..................14

IV. Substantive Aspects of Africanization of IIL: Innovative, BUT MODEST REFORMS ................................................ 18

V. Blind Spots of Moderate Africanization of International

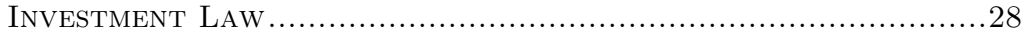

Vi. Concluding Remarks: Recalibrating the Geographies of AFricANIZATION BEYOND AfRICAN IIAs...................................32

\section{INTRODUCTION}

This article critically analyzes the on-going reforms in International Investment Law ("IIL") and policy in Africa and questions the extent to which the reforms address and remake the systemic issues in the field of IIL. IIL is enmeshed in the long history of an imperial economy. The field is notorious for the complicity of investors in the host states and the controversies that they generate. ${ }^{1}$ At the heart of any critique of IIL is a rejection of the post-colonial continuities of the technologies of governance and the asymmetry that characterizes foreign investor relations in the host states. ${ }^{2}$ An expanded understanding of the empire as a practice and structure of unequal international integration reveals the enduring continuities between Global North and Global South. ${ }^{3}$

Skepticism and backlash of IIL have grown simultaneously with existential debate about its own legitimacy. ${ }^{4}$ First, the empirical

1. See generally Ibironke T. Odumosu, The Antinomies of the (Continued) Relevance of ICSID to the Third World, 8 SAN DIEGO INT'L L.J. 345, 346 (2007); DAVID SCHNEIDERMAN, RESISTING ECONOMIC Globalization: Critical Theory And International Investment LaW, 1-2 (David Cowan ed., 2013). M. Sornarajah, Resistance And Change In The International Law On Foreign Investment (Cambridge Univ. Press ed. 2015).

2. See, e.g., Upendra Baxi, Postcolonial Legality: A Postscript from India, 45 Verfassung und Recht in Übersee/Law \& Politics in Afr., Asia \& Latin America 178, 193 (2012); David Schneiderman, The Coloniality of Investment Law, SSRN (May 21, 2019), https://ssrn.com/abstract=3392034 [https://perma.cc/3VWG-4CMQ] (exploring the continuities of colonialism and inquiring into the question whether the legal rules in the post-colony are in service of the economic interest of the metropolitan).

3. See generally Adom Getachew, Worldmaking after Empire: The Rise and Fall of Self-Determination 31-32 (2019).

4. See generally David Schneiderman, International Investments Law's Unending Legitimation Project, 49 LOY. U. CHI. L. J. 229 (2017); Julian Arato, The Private Law Critique of International Investment Law, 113 AM. J. INT'L L. 1, 2 (2019) (Demonstrating how IIL and ISDS displace and distort national private law across the fields of property law, contracts, corporations, and intellectual property, and laying the foundation for a refocused project of reform). 
evidence on the interconnectedness of foreign investment to economic growth in host states is contested. ${ }^{5}$ Critics have argued that foreign investment law entrenches the imperial and capitalist interests of multinational corporations at the detriment of host states. ${ }^{6}$ Contrary to the promise of spurring economic development in developing countries, IIL entrenches the interests of investors. ${ }^{7}$ The dilemma regarding the value of foreign investment to their economic development thus persists. ${ }^{8}$ In some cases, this has generated backlash through dissenting legislation. ${ }^{9}$ Second, dispute regimes in IIL have been effectively used in pursuit of the interests of investors. ${ }^{10}$ The

5. For example, Ghana has been attracting most of its investments from countries with which it does not have investment treaties. If investment treaties were that crucial or singular in attracting investments, Ghana and similarly placed African countries would probably not attract investments from countries with which they have not entered into investment treaties. See Dominic Npoanlari Dagbanja, Can African Countries Attract Investments Without Bilateral Investment Treaties? The Ghanaian Case, 40 Australasian Rev. African Stud. 71 (2019); Gus Van Harten, Five Justifications for Investment Treaties: A Critical Discussion, 2 Trade L. \& DeV. 19 (2010).

6. See generally John Linarelli et al., The Misery Of International Law: Confrontations With Injustice In The Global Economy, 5 (2018); SchneIderman, supra note 1, at 28; Jean Ho, The Creation of Elusive Investor Responsibility, 113 AJIL UnBOUND 10 (2019) (arguing that elusive investor responsibility was created by omission, with injurious consequences that highlight the need to alter, rather than accept, the status quo).

7. See Gus Van Harten, Investment Treaty Arbitration and Public LAw 3, 8 (Vaughan Lowe ed., 2007); Michael Waibel et al., The Backlash Against Investment Arbitration: Perceptions and Reality (Kluwer L. Int'l Working Paper, 2010).

8. Samuel K. B. Asante, International Law and Foreign Investment: A Reappraisal, 37 InT'L \& Comp. L.Q. 588, 616 (1988).

9. For example, Tanzania has proposed a series of investment reforms across various fields given the perception of unfairness against it. See Tanzania Overhauls Mining Laws, Fines Investor US\$190 Billion: Is Your Investment Protected?, Jones DAY: Insights (Aug. 2017), https://www.jonesday.com/en/insights/2017/08/tanzania-overhaulsmining-laws-fines-investor-us190-billion-is-your-investment-protected [https://perma.cc/54K8-7FXV]. See also Dilini Pathirana, Sovereign Rights to Natural Resources as a Basis for Denouncing International Adjudication of Investment Disputes: A Reflection on the Tanzanian Approach, Afronomicslaw (Sept. 11, 2020), https://www.afronomicslaw.org/2020/09/11/sovereign-rights-to-naturalresources-as-a-basis-for-denouncing-international-adjudication-ofinvestment-disputes-a-reflection-on-the-tanzanian-approach/ [https://perma.cc/LDQ2-PQCZ].

10. Antony Anghie, International Law in a Time of Change: Should International Law Lead or Follow?, 5 Am. UnIV. InT'L L. REV. 1316, 1360 (2011). 
Investor-State Dispute Settlement ("ISDS") regime is fraught with a myriad of challenges appropriately encapsulated in the regime's bias critique. ${ }^{11}$ The ISDS system's challenges arise from its transparency crisis, questions about the independence of arbitrators, contradictions between arbitral awards, underrepresentation of African arbitrators, and concerns relating to costs and time of arbitral procedures. ${ }^{12}$ Third, critical voices from the Global South - Africa in particular - have been marginalized in the ongoing ISDS reform process. ${ }^{13}$

For over a decade now, regional, sub-regional and national legal reforms across Africa have been at the forefront of IIL. ${ }^{14}$ These reforms center at the interests of African states and seek to address their subordinate position in the global economic hierarchy. ${ }^{15}$ The reforms incorporate rules for sustainable development, protection of the environment, and the rights of the marginalized. ${ }^{16}$ The 2007 Investment Agreement for the Common Market for Eastern and Southern Africa ("COMESA") Common Investment Area ("CCIA") set African states on the oath of regional investment reforms. ${ }^{17}$ Most recently, the Pan-

11. See id.; see also James Thuo Gathii, Third World Approaches to International Economic Governance, in INTERNATIONAL LAW AND THE Third World, Reshaping Justice 255, 261 (Richard Falk, Balakrishnan Rajagopal \& Jacqueline Stevens eds., 2008).

12. Lorenzo Cotula \& Terrence Neal, UNCITRAL Working Group III: Can Reforming Procedures Rebalance Investor Rights and Obligations?, South CEnTRE (Mar. 2019), https://www.southcentre.int/wpcontent/uploads/2019/03/IPB15_UNCITRAL-Working-Group-III-CanReforming-Procedures-Rebalance-Investor-Rights-and-Obligations_EN1.pdf [https://perma.cc/V28X-UMHS].

13. Won Kidane, Africa's International Investment Law Regimes, OxFoRD BIBLIOGRAPHY (Apr. 22 , 2020) https://www.oxfordbibliographies.com/view/document/obo9780199796953/obo-9780199796953-0198.xml [https://perma.cc/7A35E899]; James Thuo Gathii \& Olabisi D. Akinkugbe, Symposium Introduction: Centering Voices from the Global South on Investor-State Dispute Settlement Reform: A Debate, Afronomicslaw, (Sept. 7, 2020), https://www.afronomicslaw.org/2020/09/07/symposium-introductioncentering-voices-from-the-global-south-on-investor-state-disputesettlement-reform-a-debate/ [https://perma.cc/89FQ-TM6Y] (introducing six essays that debate and center perspectives from the Global South on Investor-State Dispute Settlement Reform and categorizing them into defenders of the ISDS regime and contributions that are critical of the system and seek reform).

14. See Schneiderman, supra note 2 , at 1.

15. Id.

16. Sornarajah, supra note 1, at 5. See generally Dominic N. Dagbanja, Africa, in Research Handbook on Foreign Direct Investment 226, 336-362 (2019).

17. See generally Investment Agreement for the COMESA Common Investment

Area, May

23 , 2007, 
African Investment Code ("PAIC") is the anchor through which African states codified their interests in IIAs. ${ }^{18}$ However, the PAIC is a model agreement with no binging effect. ${ }^{19}$ Makane Moïse Mbengue and Stephan Schill dub the innovative developments in the PAIC and other IIAs as the Africanization of IIL. ${ }^{20}$ The developments, Mbengue argues, make Africa "...an interesting laboratory for the rethinking and reshaping of international investment law." ${ }_{21}$

In this article, I draw on Third World Approaches to International Law ("TWAIL") to critically analyze the extant conceptualization of Africanization and its association with IIL. The article probes the conceptualization of "Africanization" of IIL by situating it in the broader critiques and analysis of IIL regime in the Global South. ${ }^{22}$ In particular, I immerse the Africanization thesis in the critique, reform, and remaking agenda of TWAIL. ${ }^{23}$ This analysis will deepen our understanding of the contours and blind spots of the Africanization thesis while setting a path for its normative radical calibration. ${ }^{24}$

https://www.iisd.org/toolkits/sustainability-toolkit-for-tradenegotiators/wp-content/uploads/2016/06/rei120.06tt1.pdf [https://perma.cc/SXY3-7RYT].

18. See Econ. Comm'n for Afr. Comm. of Experts, Draft Pan-African Investment Code, U.N. Doc. E/ECA/COE/35/18 (Mar. 26, 2016).

19. Id.

20. Makane Moïse Mbengue, Special Issue: Africa and the Reform of the International Investment Regime, 18 J. WORLD INV. \& Trade 371, 376 (2017).

21. Id.

22. See generally Antonius R Hippolyte, Aspiring for a Constructive TWAIL Approach Towards the Foreign Investment Regime, in FOREIGN Investment LAW AND DeVelopment: BRidging the Gap 180 (Stephan W. Schill, Christian J. Tams \& Rainer Hofmann eds., 2015).

23. Gathii, supra note 11, at 255; Upendra Baxi, Some Newly Emergent Geographies of Injustice: Boundaries and Borders in International Law, 23 Ind. J. Glob. Legal Stud. 15, 24 (2016).

24. To be sure, the aim of this article is neither to revisit questions of the evolution or contribution of Africa to the development of international investment law; questions around the substantive provisions of international investment agreements and the debates around regulatory autonomy; queries and contestations in global and regional reforms of international investment law; nor the value of regionalization vis-à-vis the global IIL regime. See generally Olabisi D. Akinkugbe, Reverse Contributors? African State Parties, ICSID and the Development of International Investment Law, 34 ICSID REV. (2019). 


\section{Moderate vs Radical Africanization of IIL}

The Africanization of IIL is about the progressive reform and remaking of the IIL regime. ${ }^{25}$ At its core, Africanization of IIL encapsulates substantive and procedural reforms of the IIL regime. ${ }^{26}$ It is about giving voice and ownership to the legislative and treaty reforms that center the interests of African states. ${ }^{27}$ African states' effort at reforming and remaking IIL span across regional, sub-regional, and national spheres, as well as IIAs or bilateral investment treaties ("BITs") between African states. ${ }^{28}$ This article makes explicit the value and inherent contradictions that animate the "Africanization" thesis in IIL.

I characterize the Africanization of IIL into two: moderate and radical. Moderate Africanization of IIL consists of modest, incremental, or piecemeal reform of IIL. While useful, the approach does not alter the fundamental unequal architecture of IIL. ${ }^{29}$ In other words, while useful, moderate Africanization of IIL keeps African states intensely enveloped in the neoliberal paradigm that underpins the IIL regime. The reformulation of Africanization principles in response to critiques sustains the market's fundamental visions of foreign investment law. ${ }^{30}$ A half-hearted reform agenda that leaves the core of IIL intact does little to substantively restructure the subordinate position of African states. While progressive, a moderate response to the asymmetry of the IIL regime engenders more challenges for African states. A moderate form of Africanization reifies and entrenches the core tenets of the received system. However, moderate Africanization has been successful in its agenda for reform. For example, the innovative provisions that distinguish them are becoming a norm in intra-African BITs and IIAs. ${ }^{31}$ But, the agenda of moderate Africanization has been limited in SouthSouth and North-South treaties. ${ }^{32}$ There is no evidence yet that the incremental reforms that are codified in the IIAs between African states

25. $I d$.

26. Id.

27. $I d$.

28. $I d$.

29. Id.

30. See generally Sornarajah Muthucumaraswamy, Mutations of NeoLiberalism in International Investment Law, 3 TRADE L. \& DEV. 203, 205 (2011).

31. See generally Wolfgang Alschner \& Dmitriy Skougarevskiy, Rule-Takers or Rule-Makers? A New Look at African Bilateral Investment Treaty Practice (NCCR Trade Regul., Working Paper No. 7, 2016).

32. Id. at 1 . 
have been transplanted beyond the continent. ${ }^{33}$ The moderate Africanization of IIL is caught in a conundrum. The conundrum is exacerbated by the asymmetry and vulnerable status of African states. Yet, one should be cautious to dismiss their influence on on-going reforms such as the lengthy United Nations Commission on International Trade Law ("UNCITRAL") reform process. ${ }^{34}$

Radical Africanization of IIL involves reform agenda where the regime is less substantively captured by Western or transnational capital interests. ${ }^{35}$ It acknowledges that IIAs have enhanced imperial domination and exploitation of host states through the mobilization of treaties, which privileges the usurpation of economic resources in the Third World. ${ }^{36}$ A reform of IIL would be radical if it curtails the spread of Western imperialism and the overreach of foreign investors that has constrained the space legislative autonomy in host states. A robust pursuit of an agenda for the radical Africanization of IIL would bring about a new international economic order that incorporates the interests of Africa and the Global South on their own terms.

Radical Africanization of IIL is ambitious, and its aim extends beyond the geographical boundaries of Africa to other peripheries. It is a revolutionary project that fundamentally requires the remaking of the international economic order that has sustained the subordinating relations between investors and host states. ${ }^{37}$ The task of radical Africanization then strikes at the heart of the unequal integration of the international economic order. In my view, escalating from a modest approach to a radical vision of Africanization that challenges the contemporary international economic and investment order would be ideal for the changes that African states seek. This is a normative call

33. Id. (analyzing the question: to what extent have African countries played an active role in the making and shaping of their bilateral investment treaties?). The authors empirically track which African states spur innovation while others do not both in the context of South-South and intra-African negotiations, $i d$.

34. Although I do not analyze this point in this article, the need to continue with this reform agenda from below can be justified on the basis of norm cascading that may occur over time. See Martha Finnemore \& Kathryn Sikkink, International Norm Dynamics and Political Change, 54 INT'L ORG., 887, 895 (1998).

35. For a movement to be transformative, it "must take advantage of the highly segmented character of social life - its fragmentation into hierarchically ordered citadels of prerogative - in order to experiment with forms of social life capable of overcoming the very oppositions between right holding and empowerment or between the quality of grand politics and the reality of practical social experience - that this segmentation helps strengthen." Roberto Mangabeira Unger, The Critical Legal Studies Movement, 96 HARV. L. REV. 561, 672 (1983).

36. $I d$.

37. Getachew, supra note 3 , at 17 . 
for a more radical Africanization of IIL. However, the inherent drawbacks of the moderate Africanization of IIL should not deter African states from moving forward with the reforms. ${ }^{38}$ African states should continue to seek opportunities to cascade these changes, even in incremental steps, as the opportunities arise.

\section{AfricAnization of International Investment LAW}

Africanization of IIL is a form of post-colonial African international legal knowledge production. ${ }^{39}$ I appropriate the concept to describe a legal process or legal phenomena that resists the established oppressive order of post-colonial continuities of international legal knowledge production. ${ }^{40}$ As a legal process, Africanization is not an end in itself, a closed set of goals, or a policy prescription. Conceptually, Africanization of IIL is an evolving critical legal phenomenon with both procedural and substantive reform agendas. ${ }^{41}$ The concept encapsulates holistic, incremental, or piecemeal reforms designed to reorder the subordination and trappings of traditional IIAs and the ISDS regime.

Africanization of IIL refers to the substantive and procedural actions by African states against the hegemony of an international

38. See Nyanje John, Hegemony in Invest State Dispute Settlement: How African States Need to Approach Reforms, Afronomicslaw (Sept. 7, 2020), https://www.afronomicslaw.org/2020/09/07/hegemony-ininvestor-state-dispute-settlement-how-african-states-need-to-approachreforms/ [https://perma.cc/S2A5-EF4M] for a provocative debate of the plight of the African states in the context of the ISDS reforms; Harrison Mbori, Exit is the Only Way Out: A Polemic Response to John Nyanje's "Hegemony in Investor State Dispute Settlement: How African States need to Approach Reforms", Afronomicslaw (Sept. 10, 2020), https://www.afronomicslaw.org/2020/09/10/exit-is-the-only-way-out-apolemic-response-to-john-nyanjes-hegemony-in-investor-state-disputesettlement-how-african-states-need-to-approach-reforms [https://perma.cc/36JT-KR2J] (arguing that while procedural reforms are important, substantive and radical reform of IIL should be foregrounded, failing which African States should exit the scene).

39. Akinkugbe, supra note 24.

40. J.T. Gathii, The Promise of International Law: A Third World View (Aug. 29 , 2020),

https://papers.ssrn.com/sol3/papers.cfm?abstract_id=3635509 [https://perma.cc/X9HJ-P862] (challenging the limited geography of places and ideas that dominate international law and arguing that the Third world is an epistemic site of production and not merely a site of reception of international legal knowledge while making a compelling case for ending the insularity of international law which is characterized by a limited set of locales and ideas); see also Ohio Omiunu, City Reports on International Law: Lagos in Focus (Sept. 7, 2020), https://papers.ssrn.com/sol3/papers.cfm?abstract_id=3688493 [https://perma.cc/WZN8-YG73].

41. See generally Akinkugbe, supra note 24 . 
investment regime that historically subjugated their economic development interests in favor of the investor. ${ }^{42}$ Africanization centers African interests in contrast to and as distinct from their Western and other Global South counterparts in IIL. ${ }^{43}$ Africanization of IIL decries and responds with substantive reforms to the knowledge, power, and information asymmetry in foreign investment law. ${ }^{44}$

Africanization of IIL should not be equated to the regionalization of the regime. Rather, it situates the broader socioeconomic, political, cultural, and sustainable development aspirations of African states with the interests of investors who enrich themselves even at the expense of the host states and their peoples. ${ }^{45}$ Africanization challenges the disruptive and exploitative impact of ISDS and IIL regimes. ${ }^{46}$ The Africanization concept that I advance acknowledges that the task of centering African interests in IIL, "is a dialectical project of engaging and overcoming untoward dimensions associated with [the African interests] while simultaneously seeking to extend, deepen, transform and democratize it as well as the structural and institutional environment within which it operates both on the national and international scene." 47

The Africanization of IIL is also an ongoing ideological struggle. This ideological struggle is part of a long history of colonial and postcolonial economic domination, inequalities in transnational legal ordering, and capital power of investors and multinational corporations. 48 As Getachew argues, "relations of economic dependence and

42. Id.

43. GetaChew, supra note 3, at 31-33.

44. Id.

45. See Anghie, supra note 10.

46. See generally Akinkugbe, supra note 24.

47. James T. Gathii, Representations of Africa in Good Governance Discourse: Policing and Containing Dissidence to Neo-Liberalism, 18 Third World Legal Stud. 65, 72 (1998-1999).

48. In calling for a "postcolonial cosmopolitanism" in response, Getachew argues that: "[t]he persistence of unequal integration and hierarchy calls for a postcolonial cosmopolitanism that recenters the problem of empire. Drawing on the critique of international hierarchy and the anticolonial efforts to build a world after empire, which are reconstructed in the following pages, this model of cosmopolitanism is less aimed at the limits of the nation-state and more concerned with the ways that relations of hierarchy continue to create differentiated modes of sovereignty and reproduce domination in the international sphere. As described above, hierarchy designates not hegemony, but processes of integration and interaction that produce unevenly distributed rights, obligations, and burdens. These processes of unequal integration are structural and embedded in the institutional arrangements of the international order. They create the international conditions of ongoing imperial domination." GETACHEW, supra note 3, at 32-33. 
inequality are often coupled with legal and political modes of unequal membership in international society." "49 The difficult task that African states confront is to devise strategies that "wage ideological and political struggle while minimizing the costs of engaging in an inherently legitimating discourse" of IIL. ${ }^{50}$ The ideological foundations of IIL are important and need to be addressed in re-ordering the investment regime and economic exploitation of host states by investors. Africanization and the legal reform that it undertakes broadly decries the violence of IIL and its technologies of governance on the economic, environmental, and sustainable development rights of African host states. ${ }^{51}$ However, ostensibly bold legal reforms may mask and legitimize continuing inequality and subordination. Legal reform alone "cannot serve as a means for fundamentally restructuring" international economic relations. ${ }^{52}$

To the extent that it engages in reforming and remaking IIL, Africanization reflects a strand of the critical agenda of TWAIL. TWAIL scholarship relies on a combination of both mainstream and critical analysis to expose the ways in which international regime obscure the socio-political and economic interests of developing countries. ${ }^{53}$ Further, to the extent that a core goal of TWAIL is a "commitment to reforming and remaking international [investment] law," 54 I contend that the Africanization of IIL is an example of substantive TWAIL response to the critique of IIL. This argument is reinforced by the fact that TWAIL is:

$[\mathrm{M}]$ ore than merely a deconstructive and oppositional movement or network of scholars, but rather one that sees the potential of reforming if not remaking international law for the greater good ... . TWAIL scholarship recognizes that international legal rules can be simultaneously repressive and liberatory. In other words,

49. Id. at 32 .

50. See Kimberlé Williams Crenshaw, Race, Reform, and Retrenchment: Transformation and Legitimation in Antidiscrimination Law, 101 HARV. L. REV. 1331, 1387 (1988).

51. See generally Oladapo Fabusuyi, Africanisation of International Investment Law: Prospects and Challenges, AfRonomiCsLaw (Oct. 18, 2019), https://www.afronomicslaw.org/2019/10/18/africanisation-ofinternational-investment-law-prospects-and-challenges [https://perma.cc/2GAB-2EZG].

52. Crenshaw, supra note 50, at 1350.

53. James T. Gathii, War's Legacy in International Investment Law, 11 INT'L Comm. L. Rev. 353, 363 (2009); see also Antony Anghie, IMPERIALISM, SOVEREIGNTY AND THE MAKING OF INTERNATIONAL LAW 196, 225-44 (2005).

54. James T. Gathii, The Agenda of Third World Approaches to International Law (TWAIL), in International Legal Theory: Foundations And Frontiers 12 (Jeffery Dunoff \& Mark Pollack, eds., 2019). 
TWAIL scholars recognize that international law is not always an instrument of colonial or post-colonial opposition, it can under certain circumstances be an instrument for or a site of liberation. ${ }^{55}$

Thus reimagined, my re-conceptualization of Africanization channels TWAIL's regime bias critique of IIL. ${ }^{56}$ Regime bias seeks to understand and appreciate "how specific legal rules . . . shape the relationship between international capital and Third World states, as well as the institutional nexus between economies, politics, and identity." 57 In recognition of the shortcomings of the legal rules of IIA for the development of African economies, Africanization seeks a reform of the system by centering the critical voices of African states in the IIAs where they have negotiation leverage. The Africanization process reimagines and reshapes the international investment regime, while acknowledging the constraints of the IIL regime.

However, as currently practiced, Africanization of IIL is at best a moderate approach to the reform of the IIL. ${ }^{58}$ It is a modest agenda at rewriting the continent's contemporary experiences into the IIA architecture. The normative call that this article makes is for a bold move towards the radical. In its radical form, Africanization of IIL does not legitimize the hegemony of traditional IIL regime. Radical Africanization does not reify Eurocentric underpinnings of IIL.

In the next section of this article, I examine the regional substantive reforms in IIL. I focus on the innovative aspects of the PAIC model agreement that are illustrative of Africanization of IIL. Essentially, my point is a simple one: the regional reforms in Africa are a moderate response to the international investment system; they are akin to window-dressing and therefore do not go far enough to alter the foundational rules of IIL.

55. Id. at $29-30$.

56. Gathii, Third World Approaches to International Economic Governance, supra note 11, at 261-62 ("the Regime Bias approach emphasizes that adverse outcome for Third world countries and poor communities within developed economies are not inevitable, and as such that such outcomes are not always traceable to a commitment to free market rules or norms. Rather, bias is traced in the way in which rules of international trade, commerce and investment are crafted, applied, and adjudicated between Third world and developed countries or between Third World countries and the interests of international capital.")

57. Id. at 265 .

58. See generally Ibironke T. Odumosu-Ayanu, South-South Investment Treaties, Transnational Capital and African Peoples, 21 Afr. J. INT'L \& Comp. L. 172 (2013). 


\section{Substantive Aspects of Africanization of IIL: InNOVATIVE, BUt Modest REForms}

Modern African IIAs differ substantively from the traditional model of IIAs. ${ }^{59}$ Modern IIAs incorporate rules that are relevant to the economic and sustainable development of developing countries. ${ }^{60}$ They are deemed progressive, unlike traditional IIAs that maintain the structure of domination by investors. ${ }^{61}$ African states have expressed their dissatisfaction with traditional IIAs at both the national and regional levels. ${ }^{62}$

I do not envision the ongoing reforms of IIL in Africa under the rubric of regionalism of IIL alone. In my view, such an approach inherently limits the innovative character of some of the investment reforms in Africa. It also, perhaps inadvertently, erases the African voice in the reform agenda of IIAs and IIL. ${ }^{63}$ To account for their views in the IIA regime, reforms undertaken by African states at the national, sub-regional, and regional (or continental) levels have introduced innovative provisions in either intra-African BITs or regional investment protocols and model agreements. ${ }^{64}$

First, at the national level, African states adopted investment laws to regulate investment within the country; the 2015 South Africa Protection of Investment Act ("Act"), which came into effect on July 13, 2018, provides a significantly limited protection of foreign

59. See generally Konrad von Moltke \& Howard Mann, Towards A Southern Agenda on International Investment: Discussion Paper on the Role of International Investment Agreements, INT'L INST. FOR SUSTAINABLE DEV. (2004).

60. See generally id.

61. See James T. Gathii, Representations of Africa in Good Governance Discourse: Policing and Containing Dissidence to Neo-Liberalism, 18 Third World Legal Stud. 65, 70 (1998-1999) (discussing idea of progress in investment sphere among Africans).

62. See Olwor Sunday Nicholas, International Law and Legal Regimes of Foreign Direct Investment in Selected African Countries (Oct. 1, 2020) (unpublished manuscript) (on file with Social Science Research Network).

63. In this regard, I agree with Stephan Schill that unlike in other regions, regionalism of African international investment law "is less an expression of fragmentation or the result of conflicting internal or external interests pulling in different directions, but a constructive step in defragmentation." Stephan W. Schill, Editorial: The New (African) Regionalism in International Investment Law, $18 \mathrm{~J}$. WORLD INV. \& TRADE, 367, 368 (2017).

64. Makane MoÏse Mbengue \& Stefanie Schacherer, Evolution of International Investment Agreements in Africa: Features And Challenges of Investment LaW "Africanization" Handbook INT'L INV. L. \& POL'Y, 2 (2019). 
investment. ${ }^{65}$ The Act grants the South African government the right to take regulatory measures to redress historical, social, and economic inequalities and injustice, foster economic development, protect the environment, uphold the rights, values, and principles of the Constitution of the Republic of South Africa, and achieve the progressive realization of socio-economic rights. ${ }^{66}$ Historically, the South African government was more open to the conclusion of BITs. ${ }^{67}$ However, the inequities that the BITs enhanced have led to their termination or deliberate lapse by the South African government. ${ }^{68}$ The Act thus fills an important void in investment regulation. However, commentators argue that the legislation significantly waters down the protection foreign investors enjoy in South Africa. ${ }^{69}$ For example, a contentious aspect of the legislation stripped away the ability of foreign investors to challenge South Africa before an international tribunal. ${ }^{70}$ In particular, the legislation makes consent to international arbitration subject to the exhaustion of domestic remedies. ${ }^{71}$ Hence, unlike investment treaties, which prescribe compulsory investor-state international arbitration outside of South Africa before an international

65. See Protection of Investment Act, Act No. 22 of 2015, Official Gazette, Vol. 606, No. 39514, https://investmentpolicy.unctad.org/investmentlaws/laws/157/south-africa-investment-act [https://perma.cc/872HXSF2]; see generally Malebakeng Agnes Forere, The New South African Protection of Investment Act, in RECONCEPTUALIZING INTERNATIONAL Investment Law From The Global South 251, 265 (Fabio Morosini \& Michelle Ratton Sanchez Badin eds., 2018); Tarcisio Gazzini, Travelling the National Route: South Africa's Protection of Investment Act 2015, 26 Afr. J. InT'L \& Comp. L. 242, 242-43 (2018).

66. Gazzini, supra note 65 , at 8, 10 .

67. See generally Dennis M. Davis, Bilateral Investment Treaties: Has South Africa Chartered a New Course, 2018 ACTA JuRIDICA 1, 2 (2018).

68. Id. at $2-4$.

69. See Phillip de Wet, Ramaphosa Just Activated a Law That Scare Foreign Investors - And Makes it Harder for Them to Fight Expropriation, Business Insider South Africa (July 13, 2018), https://www.businessinsider.co.za/protection-of-investment-actcommencement-gazetted-foreign-mediation-bee-section-25-constitution2018-7 [https://perma.cc/2WJA-32SV].

70. $I d$.

71. See Protection of Investment Act, Act No. 22 of 2015, Official Gazette, Vol. 606, No. 39514, at 9 13(5), https://investmentpolicy.unctad.org/investment-laws/laws/157/southafrica-investment-act [https://perma.cc/872H-XSF2] ("[t]he government may consent to international arbitration in respect of investments covered by this Act, subject to the exhaustion of domestic remedies. The consideration of a request for international arbitration will be subject to the administrative processes set out in section 6 . Such arbitration will be conducted between the Republic and the home state of the applicable investor."). 
tribunal, the legislation contains no compulsory referral to international arbitration at all. ${ }^{72}$ Although many see the legislation as unsupportive of investors ${ }^{73} \mathrm{I}$ argue that the measure was necessitated by the historic inequities of BITs. Hence, it is a response to the challenges of the IIL regime as opposed to a deliberate attempt to turn the country's back on investments.

Second, there have been various BITs concluded between African countries and other non-African countries; the 2016 Morocco-Nigerian BIT, which contains several innovative provisions, is a classic example of this development. ${ }^{74}$ This new breed of BIT incorporates provisions that rebalance the interests of contracting states and the investors. ${ }^{75}$ Notably, the Morocco-Nigerian BIT includes provisions that: (1) safeguard states discretion in enacting regulation and imposing obligations on investors; (2) contribute investment to the host state's sustainable development; and (3) set out an innovative pre-arbitration procedure for preventing and resolving disputes - e.g. the Joint Committee on the settlement of disputes. ${ }^{76}$ While the Joint Committee and associated "dispute prevention" mechanism are relatively novel elements in the context of BITs, the peaceful settlement of disputes is an enduring feature of the regional trade agreements in Africa. ${ }^{77}$ As such, its incorporation in the BITs is an indication of the spread of norms generated by African states in international economic and investment relations. The Morocco-Nigeria BIT thus illustrates the

72. Philip de Wet, supra note 69.

73. See id.

74. See Reciprocal Investment Promotion and Protection Agreement Between the Government of the Kingdom of Morocco and the Government of the Federal Republic of Nigeria, Morocco-Nigeria, Dec. 3, 2016, https://investmentpolicy.unctad.org/international-investmentagreements/treaty-files/5409/download [https://perma.cc/PS3Y-VK6G] [hereinafter Reciprocal Investment Promotion and Protection Agreement]; see also Okechukwu Ejims, The 2016 Morocco-Nigeria Bilateral Investment Treaty: More Practical Reality in Providing a Balanced Investment Treaty?, 34 ICSID REV. 62, 62-84 (2019). Barnali Choudhury, International Investment Law and Noneconomic Issues, 53 VAnd. J. Transnat'L L. 1, 10 (2020). In comparison, the NigeriaSingapore BIT includes more extensive provisions on health and safety, the environment and corporate social responsibility than traditional BITs. However, they do not have direct obligations on the investor in the same way as in the BIT.

75. See Reciprocal Investment Promotion and Protection Agreement, supra note 74 , at art. 15 (recognizing it is inappropriate to encourage investment by certain means).

76. Id. at arts. $23,24,26$.

77. Tiyanjana Maluwa, The Peaceful Settlement of Dispute Among African States, 1963-1983: Some Conceptual Issues and Practical Trends, 38 INT'L \& COMP L. Q. 299, 306 (1989). 
growing density of African IIL reforms aimed at centering the interests of the host states.

Third, there are sub-regional investment rules and model treaties or protocols that regional economic communities in Africa have adopted or planned to use to regulate their sub-region..$^{78}$ I will highlight four of these developments. First, the adoption of the Supplementary Act on Common Investment Rules for the Economic Community of West African States in 2008 ("Supplementary Act") 79 aims to promote investment that supports sustainable development of the Economic Community of West African States ("ECOWAS") sub-region. ${ }^{80}$ It "applies to all investments by an investor, whether the investment is made before or after the entry into force of [the] Supplementary Act." ${ }_{81}$ There are overlaps between the Supplementary Act and the MoroccoNigerian BIT; for example, the Supplementary Act prevents direct access to international arbitration for investors thereby limiting the traditional investment protections. ${ }^{82}$ This synergy bodes well for the spread of norms generated by the new intra-African BITS. Second, the adoption of the Model Bilateral Investment Treaty by the Southern African Development Community ("SADC Model BIT") in 2012. ${ }^{83}$ The SADC Model BIT stated that investments must enhance the sustainable development of the host country. ${ }^{84}$ The SADC Model BIT was not intended to be, and is not, a legally binding document. ${ }^{85}$ Instead, it offers a template for governments in their future negotiations of investment treaties. ${ }^{86}$ It suggests that a "fair administrative

78. See generally Talkmore Chidede, The Right to Regulate in Africa's International Investment law Regime, 20 OR. R. INT'L L. 437, 449-50 (2019) (examining the contemporary international investment law framework in Africa with a view to determining whether such framework preserves host states' right to regulate investment in public interest).

79. See Supplementary Act A/SA.3/12/08 Adopting Community Rules on Investment and the Modalities for their implementation with ECOWAS, December 19, 2008, https://investmentpolicy.unctad.org/internationalinvestment-agreements/treaty-files/3266/download [https://perma.cc/522Y-68XP].

80. See Ernest Amoabeng Ortsin, The ECOWAS Common Investment Market Vision: A Conceptual Preview, in FinANCING AFrICA's Development: Paths to Sustainable Economic Growth 221, 221-22 (Diery Seck ed., 2020).

81. Supplementary Act, supra note 79, at art. 4(1).

82. Id. at art. 18(1).

83. See generally SADC Model Bilateral Investment Treaty Template with Commentary, Southern African Development Community (2012).

84. Id.

85. $I d$.

86. $I d$. 
treatment" should replace the fair and equitable standard in traditional IIAs. ${ }^{87}$ Third, the adoption of the Common Market for Eastern and Southern Africa ("COMESA") and Common Investment Area ("CCIA") in 2007..$^{88}$ The CCIA agreement is a promotional tool meant to guide Member States of COMESA by harmonizing best investment practices and facilitating private sector development. ${ }^{89}$ Although it has not been ratified by any of the Member States, plans are afoot to ensure that the CCIA gains traction. ${ }^{90}$ The revised CCIA, which aligns the agreement with trends in IIL and specific standards regarding investor protection, was adopted by the Council of Ministers of COMESA in 2017. ${ }^{91}$ According to COMESA, "the revised CCIA is aligned to the Pan African Investment Code championed by the African Union. This Framework will provide a platform for the investment chapter that is the integral part of the Continental Free Trade Area ("ACFTA")." ${ }^{2}$

Fourth, on a regional level, the PAIC Model Agreement, which critically appraised traditional IIAs and provided suggestions, informs future negotiations of investment treaties. $^{93}$ The PAIC Model Agreement contains provisions aimed at limiting the standards for the protection of investments, requiring investments to foster sustainable development and creating new obligations such as human rights, due diligence, and the sustainable use of natural resources for investors. ${ }^{94}$

87. See Sonia E. Rolland \& David M. Trubek, Legal Innovation in Investment Law: Rhetoric and Practice in Emerging Countries, 39 U. PA. J. INT'L L. 358, 405 (2017).

88. See The Investment Agreement for the COMESA Common Investment Area, May 23, 2007, https://www.iisd.org/toolkits/sustainability-toolkitfor-trade-negotiators/wp-content/uploads/2016/06/rei120.06tt1.pdf [https://perma.cc/KHY3-FPM2].

89. Peter Muchlinski, The COMESA Common Investment Area: Substantive Standards and Procedural Problems in Dispute Settlement, SoAS ScHOOL Of Law Research Paper Series 1, 2 (2008).

90. See Mwangi Gakunga, Plans Afoot to Publicize Common Investment Area Agreement, ComesA (Apr. 27, 2020), https://www.comesa.int/plansafoot-to-publicize-common-investment-area-agreement/ [https://perma.cc/2W47-C865].

91. Id.

92. $I d$.

93. Won Kidane, Contemporary International Investment Law Trends and Africa's Dilemmas in the Draft Pan-African Investment Code, 50 GEO. WASH. INT'L L. REV. 523 (2018) (analyzing in historical context, with theoretical analogies, the experiences of African States with the international investment law regime and an evaluation of the PIAC in light of its purpose and developments in IIL).

94. Sustainable development is a feature of the third generation of investment agreements. Akinkugbe, supra note 24, 450. "The third generation of investment disputes involving African States starts from 2010 and runs 
The PAIC Model Agreement provides the basis for the negotiation of the ACFTA Investment Protocol..$^{95}$ The areas of innovative drafting in the PAIC include: (1) the definition of investment and investor; (2) rejection of pre-establishment commitment; (3) the clarifications of "like circumstances" as well as exceptions to national treatment under the MFN and National Treatment clauses; (4) the absence of a provision on fair and equitable treatment; (5) exceptions to the transfer of funds; and (6) performance requirements. ${ }^{96}$ The PAIC's preamble incorporates provisions important for the agreement's interpretation. ${ }^{97}$ Specifically, the preamble affirms the need to "promote corruption free investment and trade regime and improved laws and regulations that promote transparency and accountability in governance." 98 Additionally, the investment must meet the full Salini et al. v. Morocco test and should have a significant contribution to the host State's

to the present moment. Like those of previous generations, thirdgeneration disputes represent a significant and radical extension of the frontiers of issues in ICSID investment dispute jurisprudence. This category of investment disputes interestingly incorporates new themes such as sustainable development, human rights, protection of indigenous rights and environmental standards - to mention a few - in the broader discourse on international investment."). The African Society of International Law (AFSIL) Principles on international investment for Sustainable Development in Africa offer a series of guiding principles that elaborate on sustainable development goals in IIA in Africa. The AFSIL Principles "constitute an emancipatory form of contestation, whereby the application of the rules of international investment law is tailored to serve political projects valued highly by the ASIL while falling short of the ambition to revamp the universal investment protection regime." Alicia Köppen \& Jean d'Aspremont, Global Reform vs Regional Emancipation: The Principles on International Investment for Sustainable Development in Africa, ESIL Reflections (Feb. 27, 2017), https://esil-sedi.eu/esilreflection-global-reform-vs-regional-emancipation-the-principles-oninternational-investment-for-sustainable-development-in-africa-2/ [https://perma.cc/JD7M-CH3G].

95. See generally Max Mendez-Parra, Ed, AfCFTA Investment Negotiations: Notes on Concepts (May 2020), https://set.odi.org/wp-content/uploads/2020/06/Investment-TrainingNotes.pdf [https://perma.cc/6VJQ-CDA6]; Hamed El-Kady, The New Landmark African Investment Protocol: A Quantum Leap or African Investment Policy Making?, KLUWER ArB. BloG (Sept. 24, 2020), http://arbitrationblog.kluwerarbitration.com/2020/09/24/the-newlandmark-african-investment-protocol-a-quantum-leap-for-africaninvestment-policy-making/ [https://perma.cc/P284-ZE8L] (arguing that the AFCFTA Investment Protocol could result in a "quantum leap" for Africa).

96. See Econ. Comm'n for Af. Comm. of Experts, Draft Pan-African Investment Code, U.N. Doc. E/ECA/COE/35/18 (Mar. 26, 2016).

97. $I d$.

98. Id. 
economic development. ${ }^{99}$ This extension reaffirms the economic developmental model that underpins the design of IIAs in Africa. ${ }^{100}$ In this regard, Mbengue and Schacherer declare,

The PAIC is . . an African tuning or recalibration of [International Investment Agreements - IIAs]. It reflects the development that new IIAs are no longer based on either the North American or European models, but that other regions also engage in shaping IIAs according to their level of economic development and social needs. ... [It] . . endows Africa with a voice in the international debate on the future and reform of the international investment regime. ${ }^{101}$

In the context of the PAIC, Mbengue and Schacherer anchor the Africanization thesis by focusing on issues relating to developing and least-developed African countries, balancing the interests and rights of investors and host states alike, and incorporating sustainable development goals. ${ }^{102}$ The influential potential of the PAIC model agreement, especially in the course of the negotiation of the ACFTA Investment Protocol, should not be underestimated. Mouhamadou Madana Kane notes that "the Code can serve as a useful capacitybuilding instrument. It can, indeed, provide guidance to the negotiators of these agreements, in support of the continent's

99. Salini Costruttori S.P.A. v. Kingdom of Morocco, ICSID Case No. ARB/00/4, Decision on Jurisdiction, ๆ 52 (July 23, 2001).

100. Dagbanja, supra note 16 , at 362 ("The requirement in the PAIC that to qualify as an investment, the investment must make a contribution to the development of the host state is equally consistent with the development imperative that informs the making of IIAs."). See also Dominic Npoanlari Dagbanja, The Development Objective as an Imperative in Interpretation of International Investment Agreements, $44 \mathrm{U}$. OF W. Austl. L. ReV.

144, 145 (2019); See generally Dominic Napoanlari Dagbanja, The Paradox of International Investment Law: Trivializing the Development Objective Underlying International Investment Agreements in Investor-State Dispute Settlement, in Modernizing International Trade LaW to Support InNovation and Sustainable Development: Proceedings of the Congress of the United Nations Commission on International Trade LAw, 258-273 (2017).

101. Makane Moise Mbengue \& Stefanie Schacherer, The 'Africanization of International Investment Law: The Pan-African Investment Code and the Reform of the International Investment Regime, 18 J. WORLD InV. \& TRADE 414, 447-48 (2017).

102. See Makane Moise Mbengue \& Stefanie Schacherer, Africa and the Rethinking of International Investment Law: About the Elaboration of the Pan-African Investment Code, in Comparative International LaW 547, 559 (Anthea Roberts et al., eds., 2018) for the authors' explanation of the PAIC's balanced approach. 
structural transformation objectives." ${ }^{103}$ I will go further, and hope that African negotiators will heed the call by many academics to be more radical in their drafting of the investment protocol. This calls on negotiators to not only adopt some of the finest aspects of the PAIC Model Agreement, but to build on it in ways that harness the interests of African states and challenge the systemic inequities in IIL.

Premised on the foregoing substantive innovations at the national, sub-regional, and regional levels, Mbengue and Schacherer state, "the PAIC, the revised SADC Model Treaty, the new COMESA investment agreement, and the ECOWIC all consolidate a trend of 'Africanization' of IIL in the current context of reform of the international investment regime." 104 At different times, the scholars describe African states variously as international investment rule "makers" or "producers," as opposed to rule "takers" or "consumers." 105 The move by African states to "adapt the investment law game to their context, priorities and realities . . . show a new vision of Africa: that of a pioneer in setting innovative standard for the reform of the international investment

103. See Mouhamadou Madana Kane, The Pan-African Investment Code: A Good First Step, but More is Needed, 217 Colum. FDI Perspectives 1, 2 (2018) (contending that in view of the non-bindingness of the PAIC, it should be renamed "Pan-African Guiding Principles on Investor-State Relations")

104. See Makane Moise Mbengue \& Stephanie Schacherer, Evolution of International Investment Agreements in Africa: Features and Challenges of Investment Law "Africanization," in HANDBOOK OF INTERNATIONAL Investment Law And Policy, 1-23 (Julien Chaisse et al., eds., 2019); see also Makane Moise Mbengue, The Quest for a Pan-African Investment Code to Promote Sustainable Development, ICTSD: BRIDGES AFRICA (June 21, 2016), https://ictsd.iisd.org/bridges-news/bridgesafrica/news/the-quest-for-a-pan-african-investment-code-to-promotesustainable [https://perma.cc/7QPF-QFG6].

105. See generally Mbengue \& Schacherer, supra note 104 (undertaking a comparative law analysis to understand how African interests shape different approaches to international investment law and to see how the PAIC challenges traditional core approaches.); see also Mbengue \& Schacherer, supra note 104; Makane Moïse Mbengue, Special Issue: Africa and the Reform of the International Investment Regime, $18 \mathrm{~J}$. WORLD Invest. Trade 371, 371-78 (2017); Athina Fouchard Papaefstratiou, Capucine du Pac de Marsoulies, Martic Tavaut \& Clemet Fouchard, The Africanisation of Rule-Making in International Investment Arbitration, Kluwer Arbitration Blog, (Aug. 17, 2018), http://arbitrationblog.kluwerarbitration.com/2018/08/17/africanisationrule-making-international-investment-arbitration/

[https://perma.cc/6CK8-KE5K] (noting that African countries, "adapt international investment rules to their context, needs and realities and at the same time as pioneers in standard-setting activity in international investment protection."). 
law." 106 The innovative provisions of the PAIC on investment "are most appropriate and should be adopted not only in intra-African IIAs but also in IIAs involving African countries and non-African countries." 107

Mbengue and Schacherer argue further that contemporary African states are "investment rules providers" as opposed to "investment rules consumers." 108 On the one hand, African states were investment rule consumers partly because of the "asymmetry in terms of economic development between African host countries and investors' home countries." 109 On the other hand, they are investment rule providers because of the "adoption of modern investment agreements that apply in their respective region." ${ }^{110}$ Reinforcing this position, Hamed El-Kady and Mustaqeem De Gama argue that African states and their regional economic communities are no longer just rule takers, they are "investment treaty makers" and are adopting investment policies that reflect their own terms and preferences as opposed to rubber stamping transplanted models. ${ }^{111}$

Mbengue and Schacherer's latest iteration of Africanization offers a less optimistic reflection of the Africanization of IIL. The tone sharply contrasts the optimism of their previous analysis. ${ }^{112}$ Although they continue to acknowledge the uniqueness of the Africanization thesis, they were concerned that challenges, such as the implementation hurdles that the reforms will confront, the lack of binding authority of the PAIC, the stratified investment regulatory regime in Africa, and the limited geographical spread of the innovative provisions are a huge drawback on investment reform gains. To the extent that the innovative reforms in the Africanization of IIL have been mainly between African states' IIAs, and have not infiltrated the North-South IIAs, they offered some concrete suggestions to move the Africanization of IIL forward in Africa. ${ }^{113}$ They acknowledge that the innovative

106. Makane Moise Mbengue, Africa's Voice in the Formation, Shaping and Redesign of International Investment Law, 34 ICSID REV. ForEIGN INV. L. J. 455, 480 (2019) ("By fostering their own approach to the reform of international investment law aligned with their circumstances and needs, African countries are effectively 'africanizing' the development of international investment rules and the reform of the ISDS system.").

107. Dagbanja, supra note 16 , at 362 .

108. Mbengue \& Schacherer, supra note 104, at 567.

109. Id.

110. Id.

111. Hamed El-Kady \& Mustaqeem De Gama, The Reform of the International Investment Regime: An African Perspective, 34 ICSID REV. FOREIGN INV. L. J. 482 (2019).

112. Mbengue \& Schacherer, supra note 104, at 1 (distinguishing between extra-and intra African IIAs and presenting the African "spaghetti bowl" of IIAs in a straightforward manner).

113. See generally id. 
provisions that are gradually characterizing the IIAs are limited to those concluded between two or more African states or concluded by the regional economic communities. ${ }^{114}$ Essentially, African states have not been able to translate these bilateral, national, sub-regional and regional innovative provisions into IIA negotiations with Global North countries. ${ }^{115}$ Africanization of IIAs is therefore "confronted with the fact that political and economic power continue to structure and define the outcome of IIA negotiations." 116 The latest iteration by Mbengue and Schacherer reveals the limitations of moderate Africanization of IIL. ${ }^{117}$ I will return to the point in the next section.

From another perspective, in the context of economic relations among African states, other scholars have used computational measures of textual similarity to offer an analysis based on empirical evidence on the question: which African states are rule-takers and rule-makers? ${ }^{118}$ Their insight affirms the core argument of this article, that Africanization of IIL has only a moderate and limiting effect on the systemic challenges of the regime. ${ }^{119}$ In this regard, Wolfgang Alschner and Dmitriy Skougarevskiy distinguish between North-South BITs and African South-South BITs. ${ }^{120}$ On the one hand, in relation to NorthSouth BITs, African states are rule-takers. ${ }^{121}$ They have not been able to translate their innovative provisions meaningfully as part of the substantive provisions of the IIAs that the North parties negotiate. ${ }^{122}$ On the other hand, in the context of African South-South BITs, African states are rule-makers. ${ }^{123}$ Even in the context of rule-makers, not all African states hold the economic and knowledge bargain that spurs innovation in the negotiation of the BITs. ${ }^{124}$ In their analysis, Alschner

114. Id. at 2 .

115. See generally id.

116. Id. at 3 .

117. See generally Mbengue \& Schacherer, supra note 104.

118. See Wolfgang Alschner \& Dmitriy Skougarevskiy, Rule-Takers or RuleMakers? A New Look at African Bilateral Investment Treaty Practice, 1 (World Trade Inst. Working Paper No. 7, 2016) (analyzing the question: to what extent have African countries played an active role in the making and shaping of their bilateral investment treaties? The authors carefully track based on empirical analyses which African states spur innovation while others do not both in the context of South-South and intra-African negotiations).

119. Id. at 8-9.

120. Id. at 9-10

121. Id. at $8-9$.

122. Id. at 6,13 .

123. Id. at 21 .

124. Id. at 2 . 
and Dmitriy found that "smaller countries such as Mauritius or Morocco, presumably due to better in-house expertise and a more coherent investment policy agenda, are more successful in setting the terms of investment agreements." 125

To summarize, the novel aspects of African IIAs are a positive step in reorienting traditionally problematic provisions of IIAs in favor of African states. ${ }^{126}$ In other cases, some of the IIAs also balance the rights and obligations for investors and host states alike. ${ }^{127}$ They constitute a useful point of departure in the global discussion on IIA and ISDS reform - as such moderate Africanization of IIL. ${ }^{128}$ However, systemic challenges arising from power imbalance the African IIL regime remains. ${ }^{129}$ The emerging point is that the substantive translation of the Africanization of IIL in IIAs is a real dilemma for African states. In the next section, I briefly analyze these blind spots.

\section{Blind Spots of Moderate Africanization of INTERNATIONAL INVESTMENT LAW}

First, moderate Africanization of IIAs engender contradictions, reification, and the entrenchment of African states in the very system they criticize. ${ }^{130}$ These contradictions arise from the fact that, although some changes occur, they are piecemeal and might easily be described as window-dressing as they occur within the framework that has constrained and continues to constrain the economic development of the host states. Mbengue sees opportunity for African states to not only carry on their reforms on IIAs, but also to build on the universal acquis. ${ }^{131}$ He suggests that:

$[w]$ hen opportune and cost effective, the continent should utilize the tools that it readily has at its disposal. For instance, when

125. Id. at 21 .

126. See generally Mbengue \& Schacherer, supra note 104, for a discussion of the positive progress toward equity between foreign investors and African states.

127. See generally Alschner \& Skougarevskiy, supra note 118, for a review of how IIAs can balance rights in African investment treaties.

128. Gudrun Zagel, International Investment Agreements (IIAs) and Sustainable Development: Are the African Reform Approaches a Possible Way out of the Global IIA Crisis? Afronomicslaw (Oct. 31, 2019), https://www.afronomicslaw.org/2019/10/31/international-investmentagreements-iias-and-sustainable-development-are-the-african-reformapproaches-a-possible-way-out-of-the-global-iia-crisis/ [https://perma.cc/94RP-SUKQ].

129. Id.

130. See generally Mbengue, supra note 105.

131. Id. at 480 . 
negotiating which ISDS mechanism should be included in AfCFTA Investment Protocol, AU member States could take advantage of the services offered by ICSID by envisioning the creation of an ICSID focal point on the continent. ${ }^{132}$

In my view, such a recommendation will likely engender a perpetuation of post-colonial continuities that TWAIL and other critical scholars have warned against. An ICSID Center in Africa is not necessarily a problem; the challenge is that such an approach potentially makes arbitration forums in Africa less attractive. The foregoing recommendation demonstrates one of the limitations of the moderate Africanization to reform and remake IIL. The ICSID arbitration regime has been criticized as part of the broader dispute settlement architecture in IIL that is unfair to developing countries. ${ }^{133}$ TWAIL's regime bias critique queries such bodies as ICSID. ${ }^{134}$ Reverting to an ICSID focal point in Africa raises more questions than answers. ${ }^{135}$ For example, what will be the fate of many regional arbitration centers across Africa? Such a moderate Africanization approach runs into tension with the clamour by African arbitrators or those of African descent to have equal opportunity for representation of host state parties. Additionally, it will likely lead to stricter competition regime for many African law firms. ${ }^{136}$ Recently, a "new" list of arbitrators of African descent was released as part of the process that is designed to make qualified arbitrators visible. ${ }^{137}$ In my view, this is one version of Africanization that radically challenges the dominance of Western expertise in the settlement of investment disputes. The list was compiled "to [make] professionals more visible and accessible to institutions and law firms seeking individuals of colour to appoint as

132. Id.

133. Id. at 461-62.

134. See generally Gathii, supra note 11 (explaining the TWAIL framework approach).

135. United Nations UnCtad, The Rise of Regionalism in International Investment POLICYMaking: Consolidation or COMPLEXity? (2013).

136. Ibironke $\mathrm{T}$ Odumosu, The Law and Politics of Engaging Resistance in Investment Dispute Settlement, 26 PEnN St. InT'L L. R. 254, 266 (2007); Jalia Kangave, A TWAIL Analysis of Foreign Investment and Development-Induced Displacement and Resettlement: Lessons from Uganda's Bujagali Hydroelectric Project 44 Oттаwa L. R. 213 (2012).

137. Katherine Simpson \& Nancy M. Thevenin, A New List: Arbitrators of African Descent, AfricAN ARB. Ass'N (June 17, 2020), https://afaa.ngo/resources/New\%20List\%20of\%20Arbitrators\%20of\%20 African\%20Descent\%20(002).pdf [https://perma.cc/84ZA-A87G]. 
arbitrators, mediators, potential hires, conference speakers, or coauthors." 138

Second, African international investment law scholars, such as Won Kidane, contend that African states are merely codifying post-colonial continuities and the dilemmas they confront. ${ }^{139}$ Kidane contends that since the IIL regime was

made for Africa . . . When Africa . . attempts to use the normative universe for ordering intra-Africa relations it faces the same kinds of dilemmas that it faced in the immediate postcolonial period relative to colonial boundaries, colonial laws, and institutions. The dilemmas have their own history, and the history presents its own contemporary dilemmas. The PanAfrican Investment Code [he argues] . . . is nothing but a codification of these dilemmas. ${ }^{140}$

Further, Kidane argues that,

any attempt to resolve the dilemmas of history must thus answer the perennial question of whether or not the existing doctrines and institutions could be sufficiently cleansed of their imperial and colonial DNA to be meaningfully deployed for the ordering of horizontal relations among those who had endured the indignities of subordination. ${ }^{141}$

As this article contends, the task of reforming and remaking the IIL regime to address African interests requires a radical Africanization of IIL. Yet, moderate reforms to remake the system should not be discarded as irrelevant because moderate Africanization of IIL does not foreclose ongoing and progressive critique and refinement that centers African interests. Contemporary IIL is a product of a long history of domination. African states' quest to reform the IIL will not happen with a single major change. In my view, if it occurs, it will be the outcome of a constellation of moderate Africanization of IIL over a reasonable period.

Third, the moderate Africanization reform leaves African states deeply entrenched in the neoliberal trappings of IIL. ${ }^{142}$ In other words, to the extent that the reform only addresses aspects of the problem, as opposed to a radical overhaul of the regime, African states will remain constrained by the power dynamics and knowledge and information

138. Funke Adekoya, SAN, A "New" List - Arbitrators of African Descent, AFriCAN ARB. ASS'N, (June 26, 2020), https://afaa.ngo/page18097/9061705 [https://perma.cc/4BY9-828T].

139. Kidane, supra note 93 , at 525-26.

140. Id. at 526 .

141. Id. at 537 .

142. Chidede, supra note 78 , at 439 . 
asymmetry which is in favor of the investors. ${ }^{143}$ The hegemony of neoliberal policy ideas in the field of international investment law is undeniable. ${ }^{144}$ As Muthucumaraswamy Sornarajah argues, "neo-liberal principles will continue to show vitality, particularly because the dominant transnational class prefers to maintain such vitality by recasting the old structure in new forms." 145 Africanization of IIL innovation occurs within the context of IIAs that remain underpinned by a neoliberal agenda. ${ }^{146}$ Neoliberal policy set for economic and political freedom are based on stereotypes of failure "lack of political free will and economic rationality." ${ }^{147}$ Moderate and incremental reform does not therefore promise the emancipation that African countries seek by the type of reforms undertaken to date.

Fourth, the innovative characteristics of the moderate Africanization of IIL are limited to the African - regional, subregional, and national - regulatory space. ${ }^{148}$ The fact that the IIAs the African states negotiated with home state investors have not included some of the innovative provisions of IIAs in Africa reveal the limitation of the moderate and incremental approach to the remaking and reforming of IIL. ${ }^{149}$

In the concluding section of this article, I reflect on how the Africanization of IIL as a normative radical project may cascade its norms to spread its innovative provisions beyond intra-African IIAs. While the proposal may be ambitious, it offers a realistic opportunity for the constellation of moderate reforms into radical Africanization of IIL over time.

143. See Fola Adeleke, International Investment Law and Policy in Africa: Exploring a Human Rights Based Approach to Investment Regulation Dispute Settlement 8 (2018).

144. Id. at 1 .

145. Muthucumaraswamy, supra note 30 , at 205.

146. See ADELEKE, supra note 143, at 8-9 (discussing the potential legal consequences of African states' pursuit of innovation in IIAs).

147. James T. Gathii, Representations of Africa in Good Governance Discourse: Policing and Containing Dissidence to Neo-Liberalism, 18 Third World Legal Stud. 65, 71 (1998-1999).

148. See generally Alicia Köppen \& Jean d'Aspremont, Global Reform Versus Regional Emancipation: The Principles on International Investment for Sustainable Development in Africa, in Yenkong NGanguoh Hodu Moise Mbengue \& Parveen Morris, African Perspectives in INTERNATIONAL INVESTMENT LAW 18-29 (2020) (discussing the more limited approach of regional emancipation as a likelier route to IIL change than global reform).

149. See ADELEKE, supra note 143. 


\section{Concluding Remarks: Recalibrating the Geographies of Africanization beYond African IIAs}

African states confront an inevitable regime of IIL while seeking pragmatic legal strategies to re-organize their own interests in a meaningful way in contrast to those of investors. To truly have the impact it deserves, the Africanization of IIL must overcome the formal barriers that co-constitute the subordination host states. Radical systemic reform of IIL regime with consequential economic and legal ordering of the relations of international actors would be difficult to achieve. However, incremental, moderate or mere procedural windowdressing is not a desirable condition for African countries either. As this article demonstrated, a moderate Africanization of IIL, while useful, is limiting.

To address this conundrum, I contend that a constellation of moderate meaningful reforms overtime is more realistic than a single radical change. To reform and remake the traditional IIA and ISDS regime, modest achievements along the way must be acknowledged while we strive for the next "win" against an international investment regime that pillages on African resources in the name of investment. From a practical point of view, it would be utopian and naive to imagine that the IIL system will roll out the red carpet for African states or the Global South to center their concerns in IIAs. ${ }^{150}$ Perhaps a pessimistic view, but it seems difficult to see that happening today.

Since quitting the IIL system is the least of options available, African states must continue to seek critical junctures to intervene with more meaningful substantive reforms - even if moderate - that remake the international investment regime in a way that centres their own interests. To truly benefit from such piecemeal approach, there must be a longer and more normative radical strategy to the reforms.

One way to engineer such a radical normative reform is to ensure solidarity in other Global South countries. Ensuring that the IIAs concluded between Global South countries reflect these innovative provisions will push the boundaries of sustainable development, environmental protection, national policy space protection, and responsible economic investment. As Stephan Schill notes, the specific features of African regionalism in investment governance already developed "can also serve as a useful example for how regional integration in investment law and policy can lead to consolidation and ensure legitimacy in investment governance elsewhere. If other regions were to follow the African example, the development of multilateral

150. See generally Nils Gilman, The New International Economic Order: A Reintroduction, 6 Humanity 1 (2015) for a discussion of developed countries role in the failure of the New International Economic Order of the 1970 s as an appropriate reminder in this regard. 
Case Western Reserve Journal of International LaW 53 (2021) Africanization and the Reform of International Investment Law

rules and institutions that are based on genuine consensus could greatly advance." 151

151. Schill, supra note 63 , at 369 . 
Case Western Reserve Journal of International LaW 53 (2021) Africanization and the Reform of International Investment Law 